and has now been published as a Memoir of the Boston Society of Natural History (9, No. 3 ; October 1946). The work was carried out during 1939-42 in Phoenix and other localities of Arizona, and, because of its docility, its fondness for commercial sweets, and its regularity in returning to feed from artificial sources of food, the humming-bird proved to be an amenable subject for observation and experiment. The black-chinned humming-bird is strongly migratory, and its arrival on the spring breeding ground coincides with the flowering of its food plants. The sexes select and maintain isolated territories and meet on a neutral ground, the lex. Feeding habits of the humming-bird support Howard's theory of the nutritive function of territory. The monograph also describes the feeding routine, type and quantity of food consumed and the three feeding techniquesflower-probing, hovering-pecking and fly-catching. The Memoir contains twelve black-and-white plates which should delight all bird lovers.

\section{The Brotherton Collection, Leeds}

THE eleventh and twelfth reports of the Brotherton Collection Committee, University of Leeds, covering the sessions 1945-46 and 1946-47, respectively, estimate the contents of the Collection on June 30 , 1947 , as 22,700 books, 15,413 pamphlets, 473 manuscripts, 4,105 deeds, 31,158 letters and 25 maps; the increase on June 30,1946 , being 61 books, 65 pamphlets and 32 letters. Undergraduates continued to use the Collection for special studies, particularly in English literature, and the return to more normal conditions was shown by an increasing number of inquiries from abroad. Many of the visits to the Collection during 1945-46 were specially arranged in connexion with an exhibition of the collection of English county atlases and road maps presented to the University by Dr. Harold Whitaker. The practice of holding exhibitions of the Collection's treasures is to be revived, and during 1946-47 an exhibition of bindings was arranged in connexion with the Leeds Conference of the Intermational Society of Leather Trades Chemists. The re-cataloguing of books in the English literature section continued and 2,601 slips were added to the Supplementary Catalogue in 194546 and 880 in 1946-47. Ten books and pamphlets were presented in 1945-46 and 101 purchased, the corresponding figures in 1946-47 being 74 and 52 as well as 52 autograph letters presented.

\section{Linnean Society of London: Anniversary Meeting}

Ar the anniversary meeting of the Linnean Society of London held on May 24, the Linnean Gold Medal was presented to Dr. Agnes Arber, and Trail Awards and Medals were presented to Dr. Honor Bridget Fell and Dr. Cyril Dean Darlington. The following were elected officers for the session 1948-49: President: Prof. G. R. de Beer ; Treasurer : Colonel F. C. Stern ; Secretaries : Dr. B. Barnes (Botany), Dr. A. Tindell Hopwood (Zoology). The new members of council were Mr. James M. Fisher, Mr. N. B. Kinnear, Prof. W. H. Pearsall, Dr. W. R. Philipson and Mr. N. Y. Sandwith.

\section{South Eastern Union of Scientific Societies}

THE fifty-second annual congress of the SouthEastern Union of Scientific Societies will be held at Great Yarmouth during June 14-19, under the presidency of Mrs. Jacquetta Hawkes, who will speak on "Archæology and the Present". The meetings will be held in the Town Hall. The sectional presidents and the titles of their addresses are: H. J. Howard (Botanical Section), "The Mycetozoa of Sand-dunes and Marshland"; Lieut.-Colonel S. E. Glendenning (Archæological Section), "Local Materials and Craftsmanship in Norfolk Buildings"; C. D. Ovey (Geological Section), "Foraminifera in Stratigraphy with Special Reference to the Ecology of Living Forms"; Major Maxwell Knight (Zoological Section), "The Study of Bird Pellets as a Subject of Interest and Instruction to Amateur Naturalists". On June 17 there will be a "Young Naturalists' Evening", at which Nature films will be shown and a 'brains trust' held. A discussion on the functions and organisation of local societies, to be opened by G. E. W. Gosnell, will be held on June 18. The local secretary of the meeting is Mr. P. E. Rumbelow, 27 Rodney Road, Great Yarmouth; the honorary general secretary of the Union is Mr. F. J. Epps, 78 Dunwich Road, Bexleyheath, Kent.

\section{Population and World Resources in Relation to the Family}

AN International Congress on "Population and World Resources in Relation to the Family" will be held at Cheltenham during August 23-28. The programme for the Congress, which has been organised by the Family Planning Association of Great Britain, includes general sessions devoted to the following topics: world resources; essential standards of living; migration as a factor in the adjustment of national populations; sociological implications of family limitation in various typical countries; birth control as a factor in the adjustment of national population; ethical and medical advantages of planned family limitation; current and future research in problems of fertility, infertility, sex and marriage; agencies for the dissemination of knowledge and propaganda. Further particulars can be obtained from the Cheltenham Congress Organiser, 37 Park Street, London, W.1.

\section{Announcements}

Sir JAmes Chadwick, honorary fellow of Gonville and Caius College, Cambridge, and Lyon Jones pro. fessor of physics in the University of Liverpool, has been pre-elected Master of the College to succeed Mr. J. F. Cameron, who retires on September 30 .

THE Association of British Science Writers is holding its first forum discussion meeting on "Science and the Press" on June 9 at 7.30 p.m. at the Society for Visiting Scientists, 5 Old Burlington Street, London, W.1. The meeting will be open to the public and admission is free.

A RESEARCH scholarship of the value of $£ 400$ per annum and tenable for two years has been offered by the Aluminium Development Association to encourage and facilitate research in the application of light alloys to ship construction. The scholarship will be administered by a Committee of the Institution of Naval Architects and it is hoped to make the award in September. Full particulars of entry, which closes on July 31, can be obtained from the Secretary, Institution of Naval Architects, 10 Upper Belgrave Street, London, S.W.I.

Erratum. In the communication entitled "Transmission of Bactericidal Radiation through Glass" (Nature, May 29, p. 856), the lettering of the two curves should be interchanged. 